\title{
Designing a Green Electronic Unmanned Air Vehicle (GEUAV) for Supply Chain Distribution Activity in Egypt
}

\author{
Khaled EL Sakty ${ }^{a}$ and Islam Samy ${ }^{b}$
}

\author{
a Dean, College of International Transport and Logistics, Arab \\ Academy for Science and Technology and Maritime \\ Transport, \\ b International Transport and Logistics Institute for \\ Postgraduate Studies,Arab Academy for Science and \\ Technology and Maritime Transport, Cairo, Egypt.
}





\title{
Designing a Green Electronic Unmanned Air Vehicle (GEUAV) for Supply Chain Distribution Activity in Egypt
}

\begin{abstract}
In supply chain context, cargo are handled along the chain by a number of entities with varying responsibilities, including aircraft operators, express carriers, postal operators, regulated agents, consignors, consignees and ground handlers. Air cargo transport enables nations, regardless of their geographic location, to efficiently connect to distant markets and global supply chains in a speedy and reliable manner. This is vital for implementing best international business practices, including just-in-time inventory management and build-to-order production. The provision of required service level by customers is influenced by distributing products at the right time, to the right place and in the right condition. Hence, the delivery drone presents a viable option to support the initiative of maintaining service levels while reducing cost. For this purpose, this paper aims to design an Unmanned Air Vehicle (GEUAV) for delivery purposes in supply chains (SCs) in Egypt, using a green energy source. One of the main findings is current Proton Exchange Membrane fuel cells (PEMFC) cannot meet the supply chain requirements of fast dynamic response time, high peak power, low cost, and robustness. The hybrid the fuel cells with an auxiliary energy source, like Li-Ion batteries, is recommended to increase the overall energy efficiency of the Electronic Unmanned Air Vehicle (EUAV) supply system. Also, many green energy sources, such as solar and fuel cells, are available, and each has its advantages and disadvantages. Based on the requirements and limitations of air supply applications, fuel cells, and solar cells are recommended as primary sources of power for aircraft engines. On the other hand, GEUAV is more efficient delivery mode for distribution purposes in the supply chain.
\end{abstract}

Keywords: supply chain, MATLAB, distribution, Green Electric Unmanned Air Vehicle (GEUAV), drones

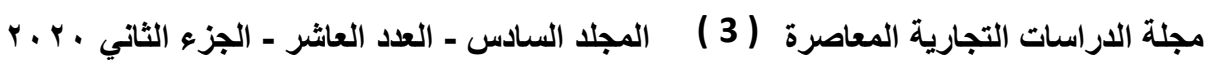




\title{
تصميم مركبة جوية إلكترونية صديقة للبيئة (GEUAV) للاستخدام
}

\author{
في نشاط التوزيع بسلاسل التوريد في مصر
}

ملخص:

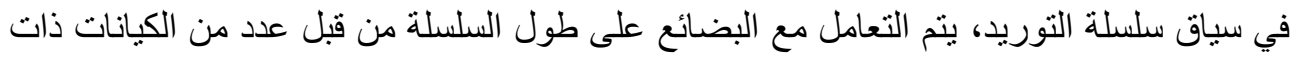

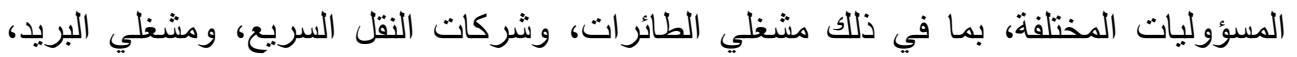

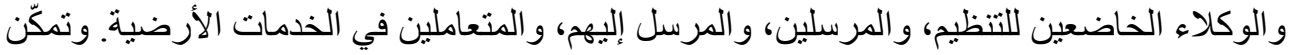

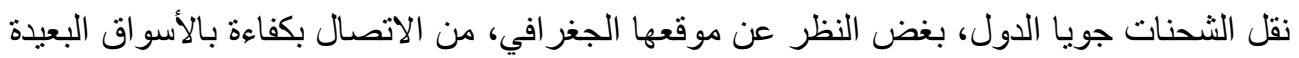

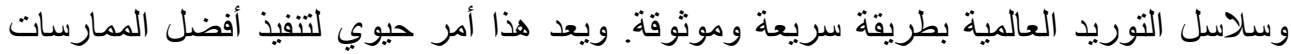

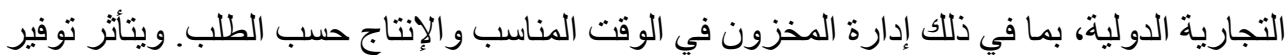

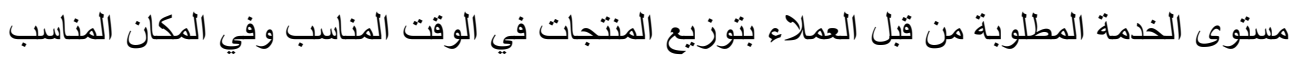

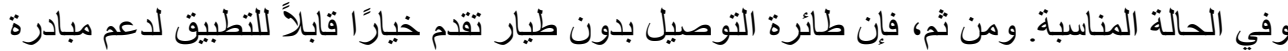

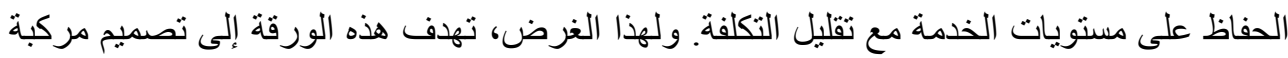
جوية بدون طيار (GEUAV) لأغر اض التسليم في سلاسل التوريد في مصر ، وباستخدام مصدر

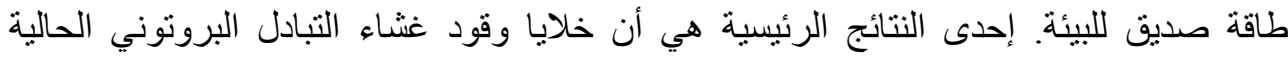
PEMFC

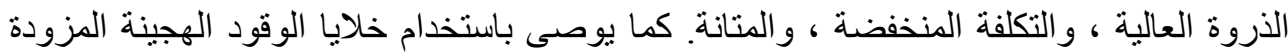

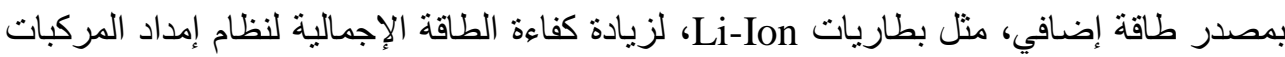

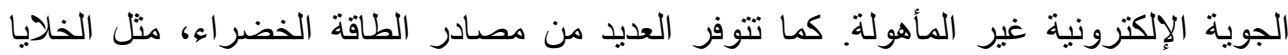

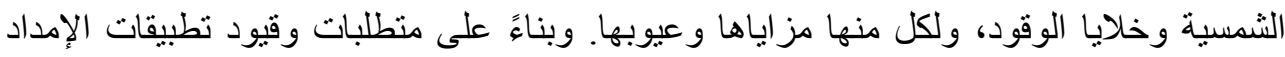

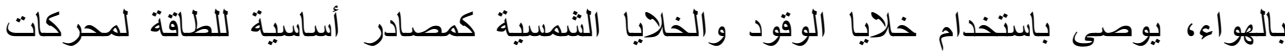

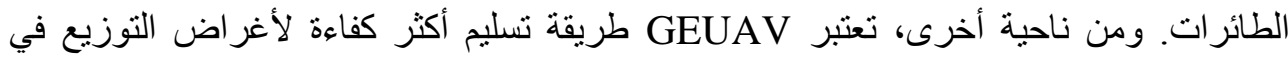
سلسلة التوريد.

الكلمات المفتاحية/الرئيسية سلاسل التوريد، MATLAB، التوزيع، مركبة كهربائية بدون طيار خضر اء (GEUAV) ، طائر ات بدون طيار 


\section{Introduction}

A supply chain consists of all parties involved, directly or indirectly, in fulfilling a customer request. To be profitable, a firm must influence the lead time to make the right goods at the right time at top quality and do so as economically as possible. From the supplier's perspective, this is the time from receipt of an order to the delivery of the product. From the customer's perspective, it may also include time for order preparation and transmittal. Customers want delivery lead time to be as short as possible, and manufacturing must design a strategy to achieve this. In this paper, the research motivation is based on improving distribution function in supply chains, using Unman air vehicles (UAVs). Unmanned Aerial Vehicles (UAVs) are unpiloted aircrafts. They are either remotely controlled (remotely piloted) or fly autonomously (self-piloted) based on preprogrammed flight plans or more complex dynamic automation systems. Nowadays, drone delivery offers tremendous benefits in the form of cheaper, faster shipping which improves delivery lead time, less costly human pilot, inexpensive, and safe way to delivery in critical areas. Also, it is used in customer delivery form disruption centre, store and truck, and in supply chain visibility like inventory inspection and movement, facilities inspection and disruption infrastructure inspection.

The Unmanned Air Vehicles (UAVs), i.e. flying drones, have received great attention in the delivery of packaged goods. Several pilot projects of commercial applications have been taken place as delivery selection to provide a fast, reliable, and convenient delivery to their customers (Vlahovic et al., 2015). Furthermore, the UAVs are also used in a small but a growing number of civil applications for missions that are too dangerous for manned aircraft (Pinto et al., 2019). This is in cases such as firefighting when a human spectator would be at risk, police observation of civil disturbances and crime scenes, and reconnaissance support in natural disasters. Moreover, drones are not only used in customer delivery form disruption centre, store, and truck, but also drones can be used in supply chain (SC) visibility, such as inventory inspection, movement inspections, facilities inspection, and disruption infrastructure inspection (Hii et al., 2019; Tatham, 2019).

However, using drones in SC faces several barriers, such as the source of power, endurance, and the delivery distance. Thus, this paper aims to design an electric UAVs with a Hybrid Power Supply System using highperformance technology to overcome the low endurance and distance barriers. To achieve this aim, an Electronic Unmanned Air Vehicle (EUAV) was designed using a MATLAB program to simulate a mission using

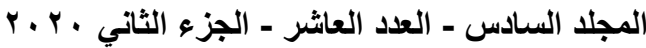

(5)

مجلة الاراسات التجارية المعاصرة 
Brushless Direct Current Motor (BLDC) as an efficient green source of power to improve the overall performance of the entire SC activities.

The remain of the paper is organised as follows. Section 2 displays the research questions and methodology. Section 3 reviews the available literature of the drones' usage in SCs. Sections 4 explains the green design of a drone for supply chain purposes, where a MATLAB simulation is used. Section 5 presents the simulation of the mission scenarios. The evaluation results and conclusion are discussed in section 6.

\section{Research Question and Methodology}

This paper has addressed the following questions:

- How can supply chain distribution function be improved?

- How can drones provide a fast, reliable, and convenient delivery to customers?

- What is role of the electronic unmanned air vehicle in supply chain delivery activities?

An exploratory approach is applied to study how to design a UAV for SC purposes. Both qualitative and quantitative approaches have been applied in designing UAV and comparing different green energy sources. A design of UAV using MATLAB simulation program for UAVs was developed using high-performance technology to overcome the barriers of SC using UAVs which face a low endurance and distance. The Proton Exchange Membrane Fuel Cell (PEMFC) is selected as the most widespread technology of fuel cell to be the UAV primary energy source.

\section{Literature Review of Drones Usage in Supply Chains}

Cargo supply chains, the process of moving consignments from origin to destination, are often complex and subject to a range of regulatory requirements, especially when they include international movements and transport by air. Air cargo is highly diverse in its physical characteristics and value. It may originate from, and be delivered to, almost anywhere in the world, most commonly as goods being sent from a seller to a buyer or from a consignor to a consignee. It can take the form of personal belongings, gifts and donations, product samples or equipment and even live animals for professional activities and events. It may be considered low risk - a regular shipment from a known source in a relatively safe region - or high risk - such as a more unusual shipment from an unknown source, presenting anomalies or identified by intelligence. The cargo will be handled along the chain by a number of entities with varying

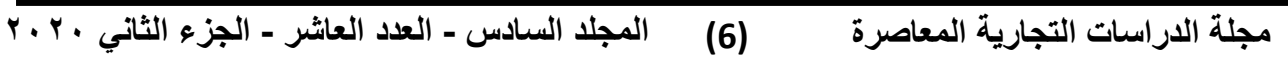


responsibilities, including aircraft operators, express carriers, postal operators, regulated agents, consignors, consignees and ground handlers. Air cargo transport enables nations, regardless of their geographic location, to efficiently connect to distant markets and global supply chains in a speedy and reliable manner. This is vital for implementing best international business practices, including just-in-time inventory management and buildto-order production

Historically, drones were initially used only by armed forces when the Austrian army first developed these vehicles for war purposes and they attacked Venice in 1849 with unmanned air balloons filled with explosives (Satia, 2014). Later, the unmanned pilots appeared after the first World War when the Sperry Gyroscope Company developed the Hewitt Sperry Automated Airplane which was the early version of today's aerial drones (Raj et al., 2016). The drones belong to a class of airborne vehicles known as UAVs. These devices can take to the air without human pilots and thus, no risk of human life (Horváth and Partners, 2019). Furthermore, the drones van be supplied with sensors or cameras to offer a clear, more comprehensive image to companies to be able to pinpoint the opportunities and threats that surround them (Lidynia et al., 2017). Table 1 shows that the UAVs have different classifications according to the flight range.

Table 1- Classification of Drones According to the Flight Range

\begin{tabular}{|l|l|l|}
\hline Category & Flight Range & Key features \\
\hline Close-range & Lower than $20 \mathrm{~km}$ & Lightless airplanes / manually start \\
\hline Short-range & 20 to $150 \mathrm{~km}$ & Operate within a restricted area \\
\hline Medium-range & 150 to $250 \mathrm{~km}$ & Superior performance \\
\hline Long-range & 250 to $500 \mathrm{~km}$ & Superior technology / for difficult missions \\
\hline
\end{tabular}

Source: Developed by the authors

Nowadays, the provision of required service level by customers is influenced by distributing products at the right time, to the right place and in the right condition. The delivery drone presents a viable option to support the initiative of maintaining service levels while reducing cost (Butcher and Lim, 2019). Druehl et al. (2018) claimed that the emergence of new technologies, such as 3D printing, virtual reality, autonomous vehicles, drones, and the Internet of Things (IoT), will force the lead to changes in global supply chains in term of new supply chain policies, business models, regulations, and also increase the risk of compromising data security. Rabta et al. (2018) considered drone applications in last-mile distribution in humanitarian logistics and presented an optimization model for the delivery of multiple packages of light-weight relief items such as vaccine via drones to a certain number of remote locations within a disaster prone area.

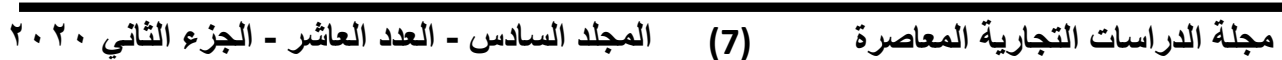


Moreover, drone transportation systems are a viable supply chain option for the transportation of blood products, which they have high financial and human cost of the units, the stringent storage conditions, limited time of storage, and the unpredictable nature of the need (Amukele et al., 2017).

The underlying question facing SC professionals nowadays is how to enhance customer service, increase profitability, and improve the entire SC performance. Several pieces of research indicated that drone delivery may be an answer (Druehl et al., 2018). A clear example of drones' delivery is Amazon's Prime Air project, where UAV hubs are determined to work as cargo depots and the delivery process of a customer order consists of multiple UAV trips (Büyüközkan and Göçer, 2018; Druehl et al., 2018). A number of companies are showcasing a wide range of drone applications for internal use within supply chain operations. Drone usage in supply chain operations seems to be falling into two categories as shown in Figure 1.

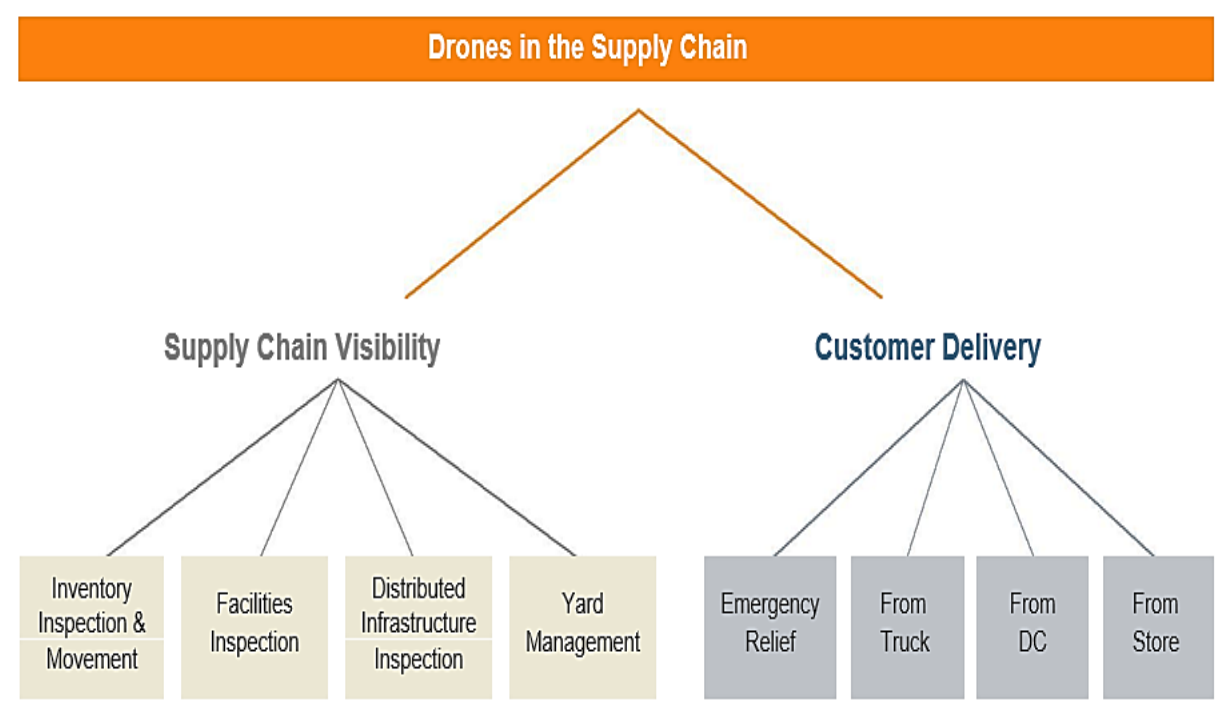

Figure 1- Drones' Usage in Supply Chain Source: Dittmann, 2017.

Figure 1 displays that drones became a major SC tool that goes well beyond customers' delivery. Haidari et al. (2016) claimed that drones will likely be used for SC visibility activities besides the customer-focused activities. A few applications of drone usage in the SC operations include, but are not limited to, inventory visibility, security, and inspection, service and repair, yard management, order picking, and transfers (Druehl et al., 2018; Haidari et al., 2016). Although, rapid customer delivery using drones can give companies a competitive edge and potentially increase market share over

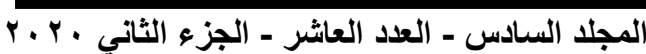

(8)

مجلة الاراسات التجارية المعاصرة 
their rivals (Druehl et al., 2018). Moreover, the usage of drones has received recently attentions in more supply chain activities as follows:

- Inventory visibility: Drone-Scan and Corvus Robotics are two examples. In these applications, a drone navigates warehouses and does a physical inventory by scanning barcodes or reading RFID tags. Several companies are also experimenting with image recognition technology to identify and track inventory. In a high-profile example, Walmart used a drone to verify inventory in one of its large distribution centers (DCs). The drone reportedly checks the entire one-million-square-foot Walmart facility in a day, as opposed to the month it takes for a human.

- Inspection: In 2016, BNSF Railway company began using drones to inspect tracks, bridges, rail yards, and monitor air quality around rail yards. The drone application adds an extra layer of inspection without increasing congestion on or around the tracks. It captures data with cameras and sensors (e.g. laser profile sensors) to detect any changes, even as small as a quarter of an inch, that could lead to safety problems. The data are coupled with predictive analytics in an attempt to forecast potential problem areas. Power companies anticipate using also drones to inspect their power stations and high voltage lines. Another inspection application could be using drones to survey roofs, outside walls, and areas around distribution centres.

- Service and repair: A large equipment manufacturer plans to use drones to deliver spare parts to keep their large, expensive equipment running in remote areas.

- Yard management: Trailer yards sit at the intersection between transportation and warehousing and are often a forgotten link in a company's supply chain. That is why yard management systems are critical to tracking and optimally managing large amounts of transportation and inventory assets.

Butcher and Lim (2019) gave a brief comparison of some of the current technology that may be adaptable to drone delivery. They claimed that most drone technology runs off battery technology, but some drones on the market like the Airborg H8 $10 \mathrm{~K}$ run off of a hybrid powerplant ("New Airborg H8 10K - Top Flight Technologies," n.d.). Battery operated platforms meet minimum performance specifications, but hybrid platforms like the Airborg offer increased range, payload, and speed as shown in figure 2. Speed, endurance, distance, and payload are critical benchmarks in drone technology to determine their relevance in supply chain enhancement.

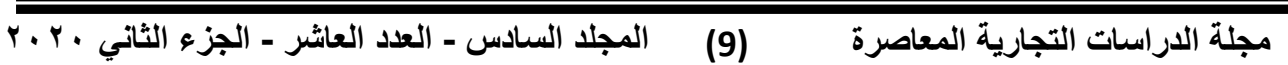


Designing a Green Electronic Unmanned Air Vehicle (GEUAV) for Supply

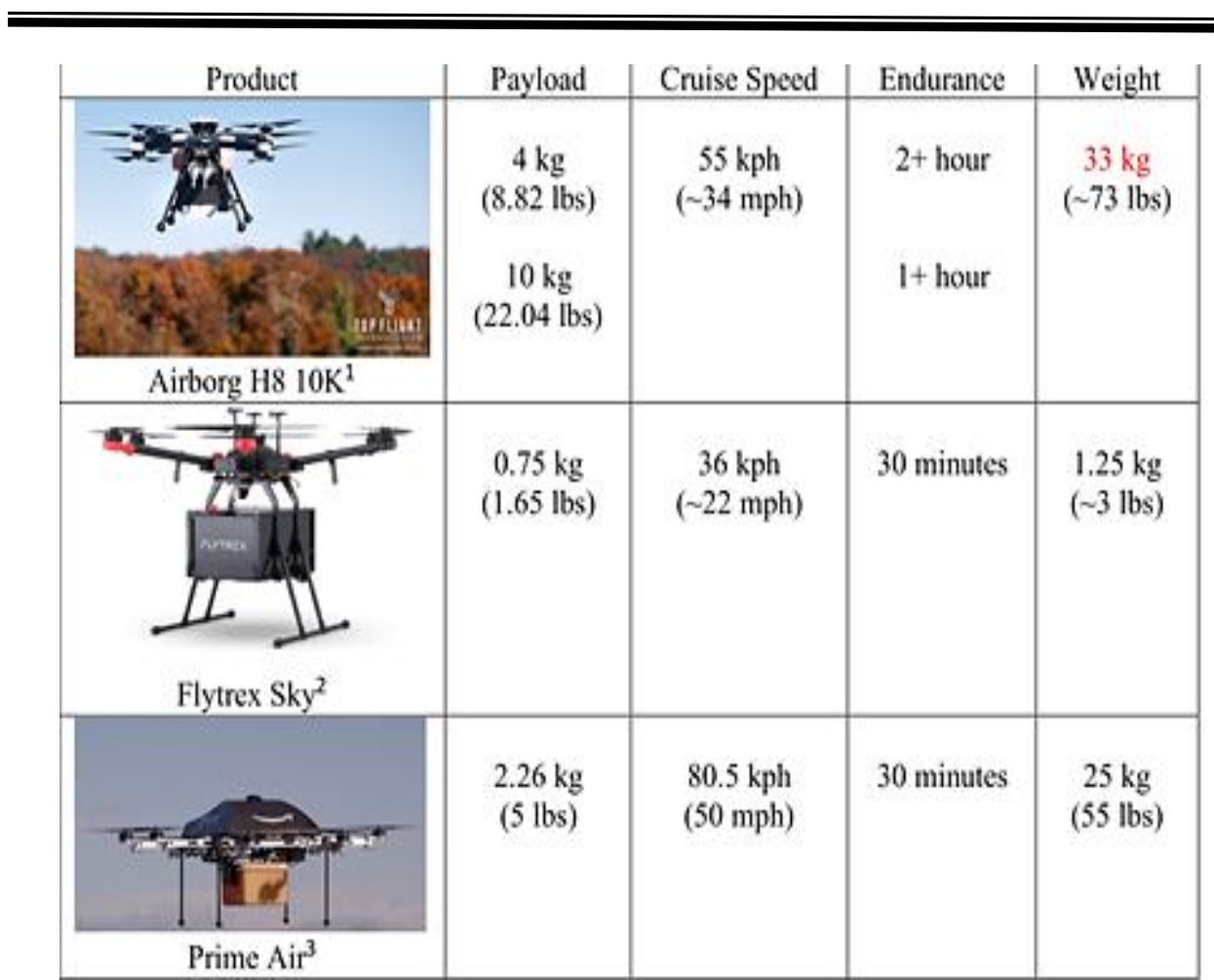

Figure 2- Drones Specifications

Drones have enormous potential but have some significant barriers to overcome. However, the usage of drones in SC face some significant barriers. Table 2 summarises most of the barriers and challenges to drone usage in the SC operations (Butcher and Lim, 2019; Dittmann, 2017).

Table 2- Barriers to Drone Usage in the SC Operations

\begin{tabular}{|l|l|}
\hline Barrier & Key elements \\
\hline $\begin{array}{l}\text { Battery life (power) and } \\
\text { endurance }\end{array}$ & $\begin{array}{l}\text { limits the range over which they can operate } \\
\text { (distance) }\end{array}$ \\
\hline Cost & Expensive / insurance cost \\
\hline Weight limitations & $\begin{array}{l}\text { the higher the weight, the stricter the flight } \\
\text { conditions }\end{array}$ \\
\hline Safety & New safety protocols needed \\
\hline Visibility & $\begin{array}{l}\text { Cannot see behind first row / cannot read } \\
\text { barcodes in dark areas }\end{array}$ \\
\hline Training issues & Training programs to pilots \\
\hline Regulatory issues & Governmental regulations/security clearances \\
\hline Weather conditions & Bad weather conditions \\
\hline
\end{tabular}

Source: Dittmann, 2017.

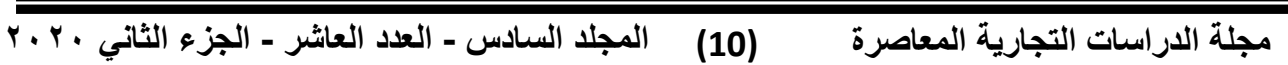


Other barriers and challenges to drone usage in the SC operations are as follows:

- Battery life: Drones will have weight limitations, an estimated fiftyfive pounds including the payload. Advanced models will likely be fit with heavier additions to avoid obstacles and control autonomous flight, limiting the range over which they can operate.

- Autonomy: Fully autonomous flight, in all conditions, is the ultimate goal. Over 80 percent of the US population lives in urban areas where autonomous delivery will be a much greater challenge in dealing with narrow aisles.

- Delivery: There are many questions surrounding delivering to residences in a secure and safe manner. A number of options are being explored, but this will be complex.

- Global integration: Regulations will vary widely from country to country.

- External conditions: How well will drones be able to operate in bad weather or even in the dark? How often would they be grounded? Challenges abound, including power lines, outdoor antennas, and indoor obstacles from large fans to dark areas.

- Safety: Drones require a new set of safety protocols.

- Cost: Drones can be expensive. Insurance costs may also increase.

- Visibility: Drones cannot necessarily see behind the first row in an inventory location or in dark areas. Barcodes or other identifiers may be obscured.

- Training: Significant training programs will need to be implemented for pilots until the drone application moves to fully autonomous.

- Public concerns: These include privacy issues and perceived danger of a drone falling.

- Aviation realities: Maintenance and inspections are time-intensive and costly.

- Insurance: Consideration and planning would be needed for how to deal with lost documents

Hence, this paper focuses on the endurance and the trip distance as stated in Table 2. This can be achieved through introducing a design of small GEUAVs with a hybrid power supply system and using high-performance technology to overcome the barriers of drones' usage in SC. Additionally, a mission scenario using a MATLAB program has been conducted to compare and select the best technique to reach the highest intended performance from the drones.

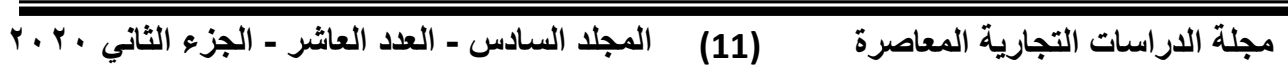




\section{Designing a Green Electronic Unmanned Air Vehicle (GEUAV) Using Simulation}

\subsection{Fuel Cell Usage in Unmanned Air Vehicle}

Although the long duration flight of fuel cell energized EUAVs have been realized only in recent five years, the conceptual design study of fuel cell energized EUAVs can be traced back to the 1980s. In 1984, NASA Langley Research Centre published a conceptual design and a preliminary performance analysis of an unmanned airplane with multi-day endurance ability. In the design, mixed-mode power supply system has been proposed in the daytime solar cells and fuel cell for the night flight. Based on the fuel cell technology at that time, the conceptual design study led to a class of airplanes with very low wing loadings and relatively long wing spans. With many successful applications of the PEM fuel cells in the automotive industry, the conceptual designs of fuel cell powered UAVs in the 2000s were much closer to realization.

In 2003, Jeffery conducted a performance assessment and an analytical feasibility of a fuel cell powered small electric aircraft based on the MCR01 two-seater plane. The results indicated that the flight with an off-theshelf fuel cell may be possible with reduced speed, climb rate, distance, and payload-carrying capabilities. Jeffery also highlighted the need for advanced technology of fuel cell to complete comparable reciprocating engine airplane performance. In the same year, researchers at Boeing Research \& Technology - Europe initiated a fuel cell demonstrator design with a fuel cell/battery hybrid configuration. With the advancement of the fuel cell technology, researchers started to investigate the integrated design optimization of fuel cell energized UAVs. Among them, researchers from Georgia Tech contributed a series of papers on the multi-disciplinary design optimization of fuel cell energized UAVs.

To improve the performance of fuel cell energized UAVs, many researchers have proposed a hybrid power system, in which both fuel cells and batteries are used for propulsion. The fuel cell is known for (low power consumption, high energy) of the density. Batteries, on the other hand, have a high-power density and the low energy density. The idea of hybridization allows the energy demand and power demand to be separated. The effect of such hybridization was investigated on the flight performance in a simulation, and it is concluded that the use of a fuel cell - battery hybrid system did not improve the endurance of a fuel cell energize UAV. Also, it is claimed that

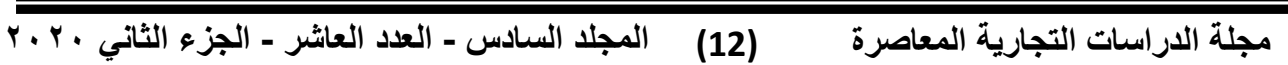


the only benefit of the hybrid power system was to decouple the design requirements of a climb flight from those of a cruise flight.

\subsection{Design of an Electromechanical Servo System}

In this paper, the designed UAV is considered to be a small long range with a payload holder. The purpose is to design of controller for controlling the rotational position output of an electromechanical servo system, which is a common building block in many position control systems. The focus is to develop appropriate control algorithms using classical control system theory. Position, in the physical sense, refers to the location of an object in space, measured by distances or a combination of distances and angles. The use of automated machinery may have Added benefits in performing repetitive work with more consistency and efficiency than can be expected from a person performing the work manual. The basic requirement for unmanned aircraft is a portable power source of electrical energy, which is transformed to mechanical energy in the electric motor for UAV propulsion. Therefore, various DC power supply sources are discussed in order to select the proper DC power source to be considered as the EUAV supply system. UAVs' power supply sources must possess the properties of high power and energy densities, fast dynamic response, and high efficiency. Specific power density is the maximum obtainable power that a supply can deliver per unit weight $(\mathrm{W} / \mathrm{kg})$ and per unit volume (W/L), respectively (Mobariz, 2016).

\subsection{Small Unmanned Air Vehicle}

Dependent on the application, Drones are classified into four size namely; Micro, small, medium and large as shown in Figure 3.

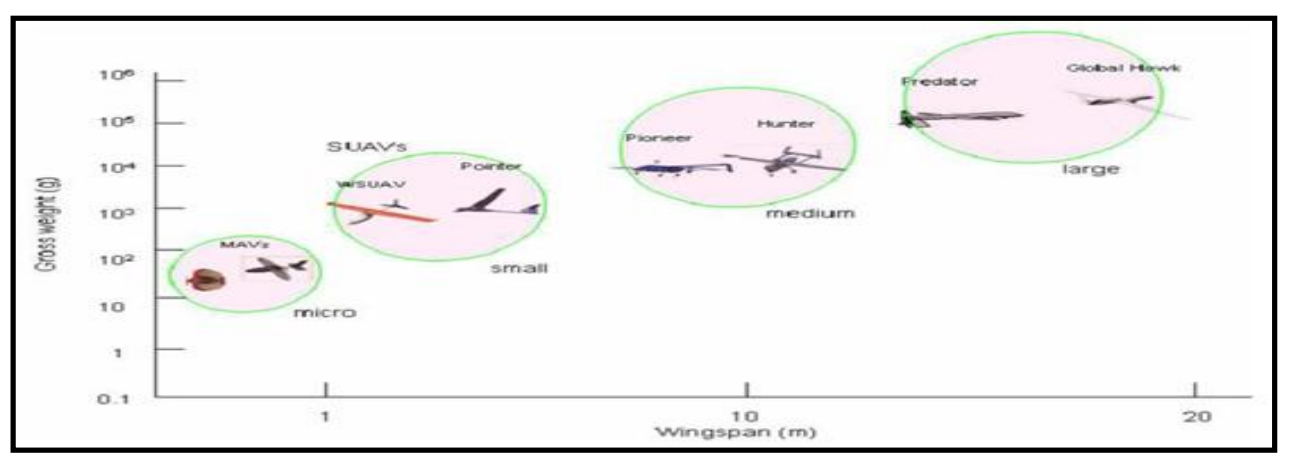

Figure 3: UAV Classification According to Size and Weight Source: Mobariz, 2016.

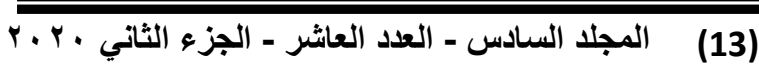
مجلة الاراسات التجارية المعاصرة 
A SUAV is easier to use and more portable than other UAVs and requires only a single operator. UAV propulsion system is the propulsive engine and its drive system. Drive system for most of the UAV, currently, can use either internal combustion engine (ICE) or the electric motor. ICEs are often used in large aircraft use due to high energy density of fuel compared to batteries required for electric motors, however electric motors have several significant advantages. A major advantage of electric motors is that they are small in size with respect to ICEs, hence most SUAVs use electric motors as propulsion systems. A EUAV is an UAV powered by an electric motor, instead of an ICE. Various electric energy sources are available for feeding the electric motors including; solar energy, hydrogen fuel cells, and energy storage sources Like, for example, super large capacity battery and super capacitor. selecting an energy source depends upon the requirements, mission and size of the EUAV.

\subsection{Electric Propulsion for EUAV}

Electric machines advance in combination with electronics advances and electricity are the basis of cofactors for electric UAVs. The electric motor is the main thrust component of a EUAV. Selecting a suitable type of motor with suitable rating is very important. These are the most commonly used motors for EUAVs: Switched reluctance machine, permanent magnet motor, induction machine, and Brushless DC motor. They have all been considered for different types of UAVs power applications. Brushed DC motors, was admired for traction systems for instance; street cars, but are not longer considered an appropriate selection because of their bulky structures, relatively less efficiency, and their need for brush and commutator maintenance, high electromagnetic interference (EMI), lower reliability than other types, and limited speed range.

\subsection{Batteries Selection for EUAV}

It is a constructed device from one or additional electrochemical cells with exterior connections to supply power to electrical devices . The battery, more specifically, and has a positive terminal (anode) and the negative (-ve) terminal (cathode) -ve terminal flows when connected to an external circuit, will be a that will electron source to transfer energy to the external device. When that connection happens, electrolytes are capable of move as ions within, permitting the chemical reactions to be fulfilled at the separate terminals and so the external electric circuit energy source, what permits current to flow out of the battery to accomplish work is the movement of those ions within the battery.

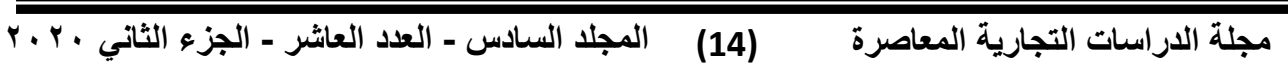


Primary batteries (single-use or disposable) are used one time and discarded. Secondary batteries (rechargeable) can be charged and discharged several times; the genuine composition of the electrodes may be recovered by reverse current. Lead-acid, Lithium-ion and other battery are examples of a secondary battery are used in UAVs and in portable electronics, respectively. The main types of rechargeable batteries used or being considered for electric and hybrid vehicle applications are as follows:

- Lead-acid.

- Nickel-Cadmium (NiCd).

- $\quad$ Nickel-metal-hydride (NiMH).

- Sodium Sulfur $(\mathrm{NaS})$.

- Lithium-ion (Li-Ion)

The first type of rechargeable batteries is a lead-acid battery that was founded in 1859. Lead acid batteries have many advantages such as; high reliability, high rates of discharge capability, low need for maintenance, low cost and low level of self-discharge. However, they have some drawbacks for example; their electrolyte and lead content that are environmentally unfriendly. Moreover, they have low energy density, poor cold temperature performance, in addition to their short calendar and limited full discharge cycles; are among the obstacles to their use in EUAVs. On the other hand, the Nickel-Cadmium Battery has low maintenance, flat discharge voltage, long life, high reliability. But their biggest drawbacks are the high cost and the toxicity contained in cadmium.

Nickel-Metal Hydride Battery has approximately two times the energy content of lead-acid batteries of the same weight. It also has a good average specific power and is also environmentally friendly. However, they have relatively high cost and low cell efficiency. Electrode chare efficiency is highly affected by temperature. So, there is a rapid drop in electrode charge efficiency at temperatures over $40^{\circ} \mathrm{C}$. Also, storage at high temperatures results in limited discharge current, degradation, limited service life, with deep cycles reducing life and high self-discharge as a result.

Sodium sulphur battery is considered the battery for the future for energy storage application. It was first developed starting 1980's. This indicates a high energy density and performance, temperature stability and low cost. Despite its several attractive features, there are several limitations; large size, the absence of an overcharge mechanism. Also its cell operating temperature is around $300^{\circ} \mathrm{C}$, which requires adequate insulation as well as a thermal control unit. Lithium-Ion is the battery system in a rapid growth. Li-Ion is used where high-energy density and

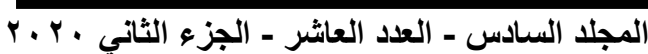

(15)

مجلة الاراسات التجارية المعاصرة 
low weight are important. They have high operating voltage levels, long cycle life, and low maintenance requirements. Their self-discharge is relatively low. However, they are expensive, very sensitive to overvoltages and over-discharges, and required a protection circuit which limits voltage. A comparison among the mentioned types of batteries is made for some features namely; specific power, specific energy, energy efficiency and cycle life.

Table 3: Battery Types Comparison

\begin{tabular}{|l|l|c|c|l|}
\hline & $\begin{array}{l}\text { Specific } \\
\text { power } \\
\text { Battery type }\end{array}$ & $\begin{array}{l}\text { Specific } \\
\text { energy } \\
\text { Lead-acid }\end{array}$ & $\begin{array}{l}\text { Energy } \\
\text { [Wh/Kg] }] \\
\text { efficiency }\end{array}$ & $\begin{array}{l}\text { Cycle } \\
\text { life }\end{array}$ \\
\hline $\begin{array}{l}\text { Nickel-Metal- } \\
\text { Hydride }\end{array}$ & $200-400$ & $60-80$ & 70 & $1000-2000$ \\
\hline Sodium Sulfur & 230 & $150-240$ & 85 & 1000 \\
\hline Lithium-ion & $200-350$ & $90-160$ & $>90$ & $>1000$ \\
\hline
\end{tabular}

Based on the desirable features of batteries for EUAV applications, table 3 shows that Li-Ion battery fulfils all the requirements, which makes it the most suitable choice among batteries. Also, concerning gravimetric energy density, the Li-Ion technology is the best compared to nickelcadmium, lead-acid, or nickel-metal-hydride. The nominal voltage of a Li-Ion cell is $3.7 \mathrm{~V}$ compared to $1.2 \mathrm{~V}$ for $\mathrm{NiCd}$ and $\mathrm{NiMH}$ and its capacity.

\subsection{Solar Energy for EUAV Design}

Photo-voltaic (PV) panel is the solar energy source that exchanges the solar energy into electrical energy with no emissions under insolation. The PV panel consists of the parallel and series connected solar cells. Current PV cells are too inefficient and it would need a large area of cells to create even a small amount of electrical energy. Consequently, a large wing span is needed for fitting the PV on the wings which results in increasing the size of the UAV.

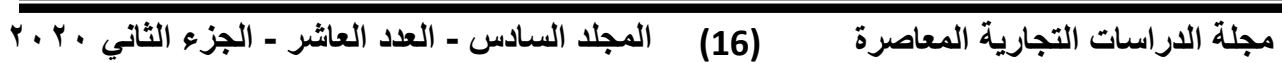




\subsection{Supercapacitors}

Supercapacitors (SCs) or ultracapacitors are energy storages having similarities with both batteries and conventional capacitors. SCs have many advantages as they can be fully charged and discharged in seconds. Also, almost linear voltage curves enables very accurate SOC estimations, and they can be recharged up to a million times. They have a long life, with less maintenance, improved low temperature performance, and environmental friendliness. However, they have some limitation as they have very low energy densities, very high selfdischarged, and their initial cost is very high.

\subsection{Fuel Cells}

The electrochemical process that sent the direct chemical process into electrical energy. Electrical energy can be generated continuously long as they are provided with a fuel cell with fuel and oxidizer. Since the establishment of the first fuel cell model by W.R. Grove in 1839, many sorts of fuel cells have been advanced. Fuel cells are used depending on the nature of the electrolyte in the cells. A comparison among the previous mentioned fuel cell types is performed as shown in table 4, in terms of the operating temperature, power range and efficiency. Based on the stated advantages and disadvantages of the fuel cell types and the, the PEMFC system is considered the most suitable choice among the fuel cell types for EUAV applications. Hence, PEMFC is chosen to be our EUAV primary energy source.

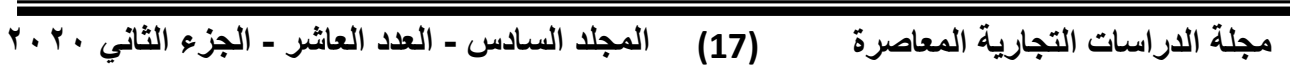


Table 4: Comparison of the Fuel Cell Types

\begin{tabular}{|c|c|c|c|c|}
\hline Fuel cell type & $\begin{array}{c}\text { Operating } \\
\text { temperature } \\
\left({ }^{0} \mathrm{C}\right)\end{array}$ & applications & $\begin{array}{c}\text { Electrical } \\
\text { power } \\
\text { range } \\
(\mathrm{KW})\end{array}$ & $\begin{array}{c}\text { Electrical } \\
\text { efficiency } \\
(\%)\end{array}$ \\
\hline $\begin{array}{l}\text { Alkaline } \\
\text { (AFC) }\end{array}$ & $70-130$ & $\begin{array}{l}\text { Space, } \\
\text { military, } \\
\text { mobile }\end{array}$ & $0.1-50$ & $50-70$ \\
\hline $\begin{array}{l}\text { Direct } \\
\text { methanol } \\
(\mathrm{DMFC})\end{array}$ & $60-120$ & $\begin{array}{l}\text { Portable, } \\
\text { mobile }\end{array}$ & $\begin{array}{l}0.001- \\
100\end{array}$ & 40 \\
\hline $\begin{array}{l}\text { Phosphoric } \\
\text { acid } \\
\text { (PAFC) }\end{array}$ & $175-210$ & $\begin{array}{l}\text { Medium and } \\
\text { large-scale } \\
\text { power } \\
\text { and CHP }\end{array}$ & $50-1,000$ & $40-45$ \\
\hline $\begin{array}{l}\text { Molten } \\
\text { carbonate } \\
(\mathrm{MCFC})\end{array}$ & $550-650$ & generation & $\begin{array}{l}200- \\
100,000\end{array}$ & $50-60$ \\
\hline $\begin{array}{l}\text { Solid oxide } \\
\text { (SOFC) }\end{array}$ & $500-1,000$ & $\begin{array}{l}\text { Medium and } \\
\text { large-scale } \\
\text { power } \\
\text { and CHP, } \\
\text { vehicle } \\
\text { APUs, off-grid } \\
\text { power and } \\
\text { micro- } \\
\text { CHP }\end{array}$ & $0.5-2,000$ & $40-72$ \\
\hline $\begin{array}{l}\text { Proton } \\
\text { exchange } \\
\text { membrane } \\
\text { (PEMFC) }\end{array}$ & $60-80$ & $\begin{array}{l}\text { Portable, } \\
\text { space, } \\
\text { low power } \\
\text { generation }\end{array}$ & $0.01-500$ & $70-80$ \\
\hline
\end{tabular}

Source: Mobariz, 2016.

Among the problems associated to PEM fuel, cells are the slow dynamic response time, and the relatively long warming up time before full power output is available. Therefore, some form of energy storage like a battery or Supercapacitors with quick charge/discharge capability can be linked to the fuel cell system to supply additional power; i.e. to function as reliable power backup during any electrical load increase or decrease.

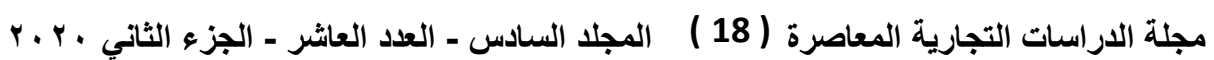


From the previous discussion, it can be summarised that the energy density is low in case of Li-Ion batteries, and it is high in the case of PEMFCs. On the other hand, the dynamic response time is slow in case of PEMFCs, and it is high in the case of Li-Ion batteries.

Thus, combined with the lithium-ion battery in PEMFC and the first power supply system, to enable the objectives of both devices and impair their shortcomings. Hence a stack of PEMFCs; as a primary energy source, and a pack of Li-ion batteries; as a supplemental energy source, will constitute the hybrid supply system.

A buck converter is planned to step-down the fuel cell stacks output voltage to a most wanted value. A PID controller is recommended for the DC-DC buck converter to assure a constant output voltage and to reject the disturbance from load and fuel cells stacks. There are three different techniques to regulate the motor speed using; speed controller with Pulse Width Modulation (PWM), cascaded control with PWM and cascaded control with hysteresis current control. When choosing PID parameters, ad-hoc methods are commonly used. These classical methods are better in providing some insight into the control design process, but more modern methods can be more effective. A multiparameter optimization technique is used in this paper for tuning gains of the PID controller; the result is less attempt and time and for tuning parameters and this will prove the ad hoc procedure on selection PID controller.

\subsection{Flight Control System}

The main objective in controlling an aircraft is to direct its orientations (attitude), in the air, to the commanded motions with respect to the inertial or reference frame. The scope of this thesis is limited to the Attitude Hold Autopilot design since the fundamental task in controlling an aircraft is to control its attitude to the commanded motions. Furthermore, the design is limited to the conventional aircraft model with no aerobatic flight envelope that is convenient to UAV aircraft.

The challenges of UAV are classified into: (i) control, (ii) guidance, (iii) aerodynamics, (iv) inertia and (v) propulsion system. The key features in aeronautics are stability and control. The problem in flight control system design is to maintain the aircraft stability in spite of the different types of uncertainties. In fact, an aircraft in flight is a very complicated dynamic system due to the included high nonlinear modes. Moreover,

المجلا السادس - العدد العاثر - الجزء الثاني . r. r.

(19)

مجلة الاراسات التجارية المعاصرة 
wide changes in flight conditions contribute to alter aircraft aerodynamic parameters. Holding an aircraft, within a specific state, is a difficult process in the presence of high frequency modes. This requires achieving constant and continuously efforts to correct the aircraft toward its desired state.

The correction process should be as smooth as possible with neither a significant overshoot or exceeding time domain constraints, and within limitations of the airframe. To address these problems, flight control systems are designed utilizing both classical and advanced techniques. In this paper, time domain design technique and frequency domain robust control design technique are chosen as examples to classical and advanced techniques. The design process starts by developing a mathematical model for the aircraft to analyze its motion in both time and frequency domains.

The classical control such as PID controller, being the simplest one, is probably the most-used feedback control design. "PID" means Proportional-Integral-Derivative, referring to the three terms operating on the error signal to produce a control signal. PID controllers are the most established class of control cases. In contrast to the classical control, advanced control utilizes the state space representation in which a mathematical model of a physical system is represented as a set of input, output and state variables related by first-order differential equations. Therefore, variables representing inputs, outputs and states are expressed in terms of matrix form.

The state space representation provides a convenient and compact way to model and analyze systems with multiple inputs and outputs. There are many advanced control techniques with the main objective to overcome disadvantage of classical techniques. When dealing with multi-conflict objectives, it is intended to improve performance and stability robustness, besides saving cost and time for designing control system utilizing available technology. A controller is said to be robust when it manipulates the unknown plants with unknown dynamics subjected to unknown disturbances. However, a key issue with robust control system is the uncertainty and how the control system deals with it. There are several reasons to interpret this uncertainty: imperfect plant data, time varying plant, higher order dynamic, non-linearity, complexity, skills.

The design of robust control is based on the worst case scenario, therefore, it is well suited for applications where stability and reliability

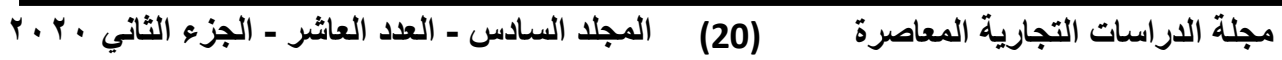


are the top priorities, plant dynamics are known, and variation ranges for uncertainties can be estimated. It is a control system that has the ability to adjust its characteristics in a changing environment in order to maintain an optimal operation according to some specific criteria. It is either model reference or self-tuning which requires some kind of identification for the plant dynamics. A predictive controller is a controller that is based on the predictive model of the plant. The model is used to predict the future output based on the historical information of the plant as well as the future input. It calculates the future control action based on a penalty or performance function.

The optimization of predictive control is limited to a moving time interval and is carried on continuously on-line. The moving time interval is called a temporal window. A predictive control is based on three elements: predictive model, optimization in range of a temporal window and feedback correction. Optimal Control is a control system devoted to find a feasible controller to transfer the system state from a given initial condition toward the objective set, and minimizes a performance index. Intelligent control refers to a control that uses various artificial intelligence techniques such as learning control, expert control, fuzzy control, and neural network control.

\section{Aerospace Mission Scenario}

The specifications of the control systems are generally related to transient and frequency response such as overshoot, speed of response, phase margin and gain margin. Some specifications concerning the aerospace applications and have to be satisfied by the autopilot such as: (i) rise time $\leq 0.5$ second, and (ii) maximum peak overshoot percentage $\leq 5 \%$ and reject $50 \%$ of the distance within 1.5 second and $95 \%$ within 4 second. Toward these objectives; the classical and advanced controllers are to be designed and evaluated. Analysis and design of the monitoring and interfacing system component are presented in this section. These include the dc-dc buck converter that interfaces the fuel cell stack with the dc-link, and its associate controllers, and motor drive system controller using various control techniques; speed control with PWM, cascaded control with PWM and cascaded control with hysteresis current control.

These several fling modes mission is utilized to show the capabilities and performances of the designed components. The UAV's mission involves

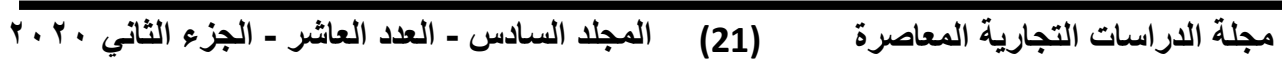


several flying modes such as take-off, climbing, cruising, steady-state turning, descent and landing as shown in figure 4. Start the procedure to use the power supply to the driving motor of the rapid dynamic response times of milliseconds, as it is a lithium-ion battery.

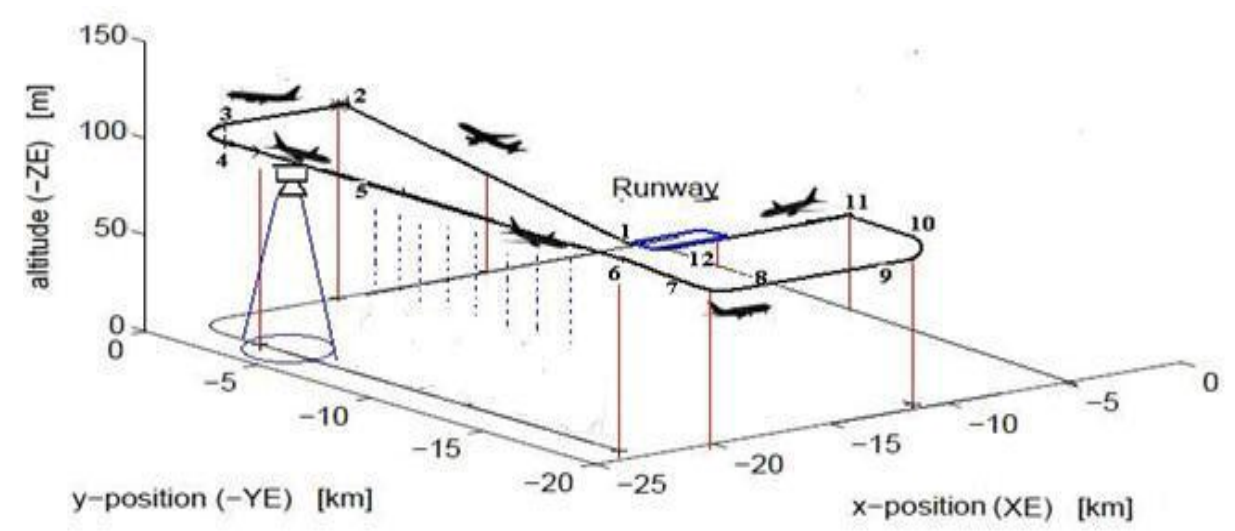

Figure 4- The UAV's mission involves several flying modes

Then, after 30 hours, the fuel pump of hydrogen therefore turned on fuel to the fuel cell takes about 30 seconds, to supply the fuel cell reaction, and the stack is heated in order to achieve the performance and maximum efficiency, it will be the battery, which for made available, and from then. The mission of the UAV launch and then to rise mode and take-off. Using the elevator control surface, it is continued until the desired height is reached. Then UAV, both the aileron and rudder control surface start with horizontal to fly towards the destination. The camera is turned on in order to ensure to reach the desired intermediate position, 9 minutes after the flight, the unit of about 45 minutes, there was a reconnaissance survey. Use after the end of its mission, the UAV, the elevator control surface is down mode, it will return to reach the landing site again in both the aileron and rudder control surface. The amounts of power consumed by the loads vary according to their resistant loads. Table 5 summarizes the scenario of unmanned reconnaissance aircraft mission to promote BLDC motor, it shows the load of the control surface actuators and other load.

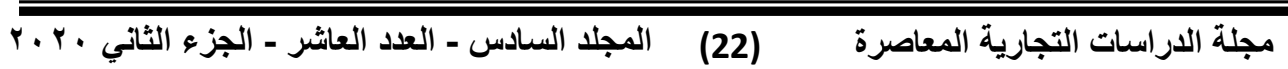


Designing a Green Electronic Unmanned Air Vehicle (GEUAV) for Supply

Table 5- Scenario of Unmanned Reconnaissance Aircraft Mission

\begin{tabular}{|c|c|c|c|c|}
\hline Process & $\begin{array}{c}\text { Time } \\
\text { interval } \\
\text { [min] }\end{array}$ & Description & Source & Loads \\
\hline 1 & $0-1$ & $\begin{array}{c}\text { Startup } \\
\text { Battery ON }\end{array}$ & $\begin{array}{l}\text { Battery via } \\
\text { buck }\end{array}$ & Propeller thrust \\
\hline 2 & $1-1.15$ & Battery OFF & $\begin{array}{l}\text { Fuel cell via } \\
\text { buck }\end{array}$ & Propeller thrust \\
\hline 3 & $1.15-3$ & Climbing & $\begin{array}{l}\text { Fuel cell via } \\
\text { buck }\end{array}$ & $\begin{array}{c}\text { Propeller thrust+ } \\
\text { elevator }\end{array}$ \\
\hline 4 & $3-6$ & $\begin{array}{l}\text { Horizontal } \\
\text { flight }\end{array}$ & $\begin{array}{l}\text { Fuel cell via } \\
\text { buck }\end{array}$ & Propeller thrust \\
\hline 5 & $6-6.5$ & $\begin{array}{l}\text { Drop the } \\
\text { payload }\end{array}$ & $\begin{array}{l}\text { Fuel cell via } \\
\text { buck }\end{array}$ & $\begin{array}{l}\text { Propeller thrust } \\
\text { + ailerons } \\
\text { +rudder }\end{array}$ \\
\hline 6 & $6.5-9$ & $\begin{array}{l}\text { Horizontal } \\
\text { flight }\end{array}$ & $\begin{array}{l}\text { Fuel cell via } \\
\text { buck }\end{array}$ & Propeller thrust \\
\hline 7 & $9-9.5$ & $\begin{array}{l}\text { Drop the } \\
\text { payload }\end{array}$ & $\begin{array}{l}\text { Fuel cell via } \\
\text { buck }\end{array}$ & $\begin{array}{l}\text { Propeller thrust } \\
\text { +Payload holder }\end{array}$ \\
\hline 8 & $9.5-10$ & $\begin{array}{l}\text { Horizontal } \\
\text { flight }\end{array}$ & $\begin{array}{l}\text { Fuel cell via } \\
\text { buck }\end{array}$ & Propeller thrust \\
\hline 9 & $10-55$ & Cursing & $\begin{array}{c}\text { Fuel cell via } \\
\text { buck } \\
\text { Fuel cell } \\
\text { direct }\end{array}$ & Propeller thrust \\
\hline 10 & $55-59$ & $\begin{array}{l}\text { Horizontal } \\
\text { flight }\end{array}$ & $\begin{array}{l}\text { Fuel cell via } \\
\text { buck }\end{array}$ & Propeller thrust \\
\hline 11 & $59-60$ & Turning & $\begin{array}{l}\text { Fuel cell via } \\
\text { buck }\end{array}$ & $\begin{array}{c}\text { Propeller thrust } \\
+ \text { ailerons + } \\
\text { rudder }\end{array}$ \\
\hline 12 & $60-75$ & $\begin{array}{l}\text { Horizontal } \\
\text { flight }\end{array}$ & $\begin{array}{l}\text { Fuel cell via } \\
\text { buck }\end{array}$ & Propeller thrust \\
\hline 13 & $75-76$ & Turning & $\begin{array}{l}\text { Fuel cell via } \\
\text { buck }\end{array}$ & $\begin{array}{l}\text { Propeller thrust } \\
\text { +ailerons+ } \\
\text { rudder }\end{array}$ \\
\hline 14 & $76-80$ & $\begin{array}{l}\text { Horizontal } \\
\text { flight }\end{array}$ & $\begin{array}{l}\text { Fuel cell via } \\
\text { buck }\end{array}$ & Propeller thrust \\
\hline 15 & $80-82$ & Descending & $\begin{array}{l}\text { Fuel cell via } \\
\text { buck }\end{array}$ & $\begin{array}{l}\text { Propeller thrust } \\
+ \text { elevator }\end{array}$ \\
\hline
\end{tabular}

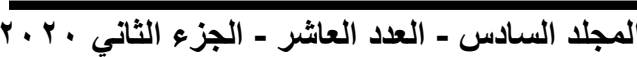

(23)

مجلة الدراسات التجارية المعاصرة 


\section{Conclusion}

As a contribution to the research, an EUAVs is designed using a MATLAB program to overcome the barriers of supply chain in term of a low endurance and distance. In this paper, the mainly significant energy storage; batteries, PVs, supercapacitors, and fuel cells, are discussed in detail. PEMFC as the most widespread technology of fuel cell is selected to be the EUAV primary energy source. But current PEMFCs cannot meet the requirements of fast dynamic response time, high peak power, low cost, and robustness. Therefore, a decision is made to hybrid the fuel cells with an auxiliary energy source like Li-Ion batteries to increase the overall energy efficiency of the EUAV supply system.

It is concluded that there is an unprecedented wave of innovation engulfs today's SC professional's new breakthrough developments, such as drones. These developments incorporated with the emerging technologies could generate hundreds of thousands of new jobs and hundreds of billions of dollars for the economy over the next ten years.

UAVs have gained in importance due to their involvement in many military and civilian applications. These applications include air supply systems, which require small vehicle sizes, low sound and heat emission levels, reduced cost and increased volume of cargo to be transported by air. It can be concluded that traditional internal combustion engines generate loud sounds and emit a large amount of heat as well as large size and weight, so it is preferable to use electric engines for drones operating in such applications.

One of the electric motors that can be used by electric drones is the BLDC. These engines have many advantages and have been used as propulsion engines for electric aircraft. These advantages include high reliability and efficiency, small engine size and weight, long operating life, high dynamic response, low noise during work, high torque-to-weight ratio and the possibility of increased cargo to be transported by air.

Batteries are a main source of power for electric drone engines, but due to the low battery density and the length of time required to charge them, batteries alone are not enough to provide the energy needed for long-range flights. Therefore, this message focuses on renewable and clean energy sources for electric drone engines to increase the range of the aircraft.

Many green energy sources, such as solar and fuel cells, are available, and each has its advantages and disadvantages. Based on the requirements and

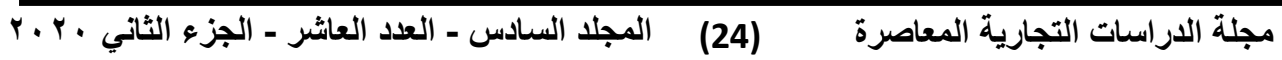


limitations of air supply applications, fuel cells, and solar cells have been selected as primary sources of power for aircraft engines. The power supply combines fuel cells, solar cells, and batteries (hybrid system) and allows the exploitation of the advantages of each of these sources and reduces the defects of the other.

After selecting the BLDC to be the driving engine of the drone and after the construction of the electric power supply system, this piece of work was concerned with studying and improving the overall performance of air transport systems and comparing different techniques to select the best techniques to reach the highest performance for air supply transportation system. 


\section{References:}

- Amukele, T., Ness, P.M., Tobian, A.A., Boyd, J. and Street, J., 2017. Drone transportation of blood products. Transfusion, 57(3), pp.582-588.

- Burgett, L.M. and Takahashi, T.T., 2019. Comparison of Vaneless Counter-Rotating Power Extraction Engines for UAV Propulsion. In AIAA Aviation 2019 Forum (p. 3016).

- Butcher, B. and Lim, K., 2019. Assessing Feasibility of the Delivery Drone.

- Büyüközkan, G. and Göçer, F., 2018. Digital Supply Chain: Literature review and a proposed framework for future research. Computers in Industry, 97, pp.157-177.

- Coates, E.M., Wenz, A., Gryte, K. and Johansen, T.A., 2019, June. Propulsion System Modelling for Small Fixed-Wing UAVs. In 2019 International Conference on Unmanned Aircraft Systems (ICUAS) (pp. 748-757). IEEE.

- Druehl, C., Carrillo, J. and Hsuan, J., 2018. Technological Innovations: Impacts on Supply Chains. In Innovation and Supply Chain Management (pp. 259-281). Springer, Cham.

- Druehl, C., Carrillo, J. and Hsuan, J., 2018. Technological Innovations: Impacts on Supply Chains. In Innovation and Supply Chain Management (pp. 259-281). Springer, Cham.

- Haidari, L.A., Brown, S.T., Ferguson, M., Bancroft, E., Spiker, M., Wilcox, A., Ambikapathi, R., Sampath, V., Connor, D.L. and Lee, B.Y., 2016. The economic and operational value of using drones to transport vaccines. Vaccine, 34(34), pp.4062-4067.

- Hii, M.S.Y., Courtney, P. and Royall, P.G., 2019. An evaluation of the delivery of medicines using drones. Drones, 3(3), p.52

- Horváth and Partners, 2019. Urban Air Mobility Study Report 2019. Stuttgart.

- Jones J D, and Fuller C R. An experimental investigation of the interior noise control effects of propeller synchrophasing. NASA Technical Report. NASA CR-178185. National Aeronautics and Space Administration, 1986.

- Kumar R, Nemati A, Kumar M, et al. Position and attitude control by rotor tilt and rotor speed synchronization for single axis tilting-rotor quadcopter. In: ASME 2017 Dynamic Systems and Control Conference. American Society of Mechanical Engineers. Tysons, 2017. V003T39A005

- $\quad$ Lan, S., Rouaud, C., Stobart, R., Chen, R., Yang, Z. and Zhao, D., 2017. The potential of thermoelectric generator in parallel hybrid vehicle applications (No. 2017-01-0189). SAE Technical Paper.

- Li, Y. and Cheng, X., 2017, October. New deterministic and statistical simulation models for non-isotropic UAV-MIMO channels. In 2017 9th

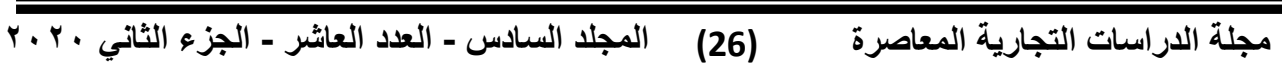


International Conference on Wireless Communications and Signal Processing (WCSP) (pp. 1-6). IEEE.

- Lidynia, C., Philipsen, R. and Ziefle, M., 2017. Droning on about dronesacceptance of and perceived barriers to drones in civil usage contexts. In Advances in human factors in robots and unmanned systems (pp. 317329). Springer, Cham.

- Mobariz, K. (2016). PhD. Cairo: Study and Analysis of Unmanned Air Vehicles (UAV) Power System Energized by Fuel Cell.

- Pinto, R., Zambetti, M., Lagorio, A. and Pirola, F., 2019. A network design model for a meal delivery service using drones. International Journal of Logistics Research and Applications, pp.1-21.

- Rabta, B., Wankmüller, C. and Reiner, G., 2018. A drone fleet model for last-mile distribution in disaster relief operations. International Journal of Disaster Risk Reduction, 28, pp.107-112.

- Raj, A.N.J., Chawla, A., Sridhar, G. and Akshay, D., 2016, December. A Comparative Study of Pre-processing Techniques for Marker Based Localization in UAVs. In International Conference on Soft Computing and Pattern Recognition (pp. 419-428). Springer, Cham.

- Rau D, Rodina J, Palkovič L, et al. Sensorless field oriented control of BLDC motors for MAVs. Trans Electric Eng, 2015, 4: 91- 96

- Satia, P., 2014. Drones: a history from the British Middle East. Humanity: An International Journal of Human Rights, Humanitarianism, and Development, 5(1), pp.1-31

- Song, Z., Li, J., Hou, J., Hofmann, H., Ouyang, M. and Du, J., 2018. The battery-supercapacitor hybrid energy storage system in electric vehicle applications: A case study. Energy, 154, pp.433-441.

- Tatham, P., 2019. Drones to the Rescue: A Case Study of Cyclone PAM. In Unmanned Aerial Vehicles in Civilian Logistics and Supply Chain Management (pp. 115-136). IGI Global.

- Vlahovic, N.I.K.O.L.A., Knezevic, B.L.A.Z.E.N.K.A. and Sabolic, M.I.L.A.N.A., 2015. Overview of Recent IT Technologies in Retail Supply Chains. Recent Advances on Business, Economics and Development, pp.31-38.

- Zhao, J., Gao, F., Kuang, L., Wu, Q. and Jia, W., 2018. Channel tracking with flight control system for UAV mmWave MIMO communications. IEEE Communications Letters, 22(6), pp.1224-1227.

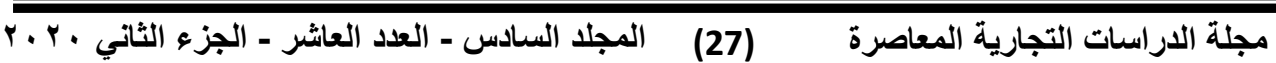


